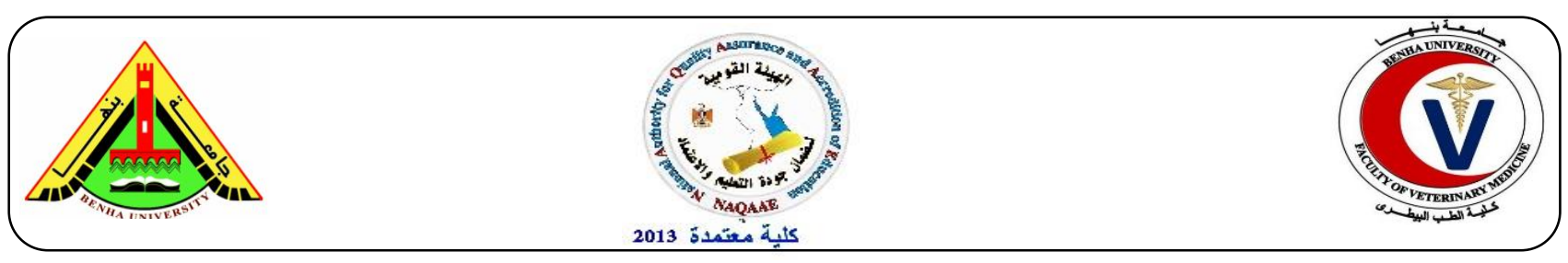

\title{
Histological and Some Immunofluorescence Studies on the Gills epithelium of the Gray Mullet (Mugil Cephalus) with reference to the age
}

\author{
Mona Nasr Abdelnaeim Hussein ${ }^{1,2}$ and Xiaojuan Cao*1 \\ ${ }^{1}$ College of Fisheries, Key Lab of Agricultural Animal Genetics, Breeding, and Reproduction of Ministry of \\ Education, Huazhong Agricultural University, Wuhan, Hubei 430070, China. \\ ${ }^{2}$ Department of Histology and Cytology, Faculty of Veterinary Medicine, Benha University, Egypt. \\ Corresponding author*: Xiaojuan Cao Mail: caoxiaojuan@mail.hzau.edu.cn
}

\section{ABSTRACT}

Mugil cephalus fish is from euryhaline fish, so its gills have the ability for accommodation in both fresh and marine water. We studied the histological changes in gill epithelium at the age of three, six, eight months and one year as well as, expression of PPAR $\alpha$, PPAR $\gamma$, BCL-2, BAX, KI67, and PCNA in gills epithelium. We used hematoxylin and eosin staining for general histological observations. As well as, we detected Immunofluorescence of PPAR $\alpha$, PPAR $\gamma$, BCL-2, BAX, KI67, and PCNA antibodies. General histological observations detected that the gill filament was supported by hyaline cartilage and some connective tissue fibers, from the gill filament several secondary lamellae projects. There were several kinds of cells present in gill filament and secondary lamellae; mitochondria-rich cells (MRCS), pavement cells, mucous cells, red blood cells, pillar cells, melanincontaining macrophage and undifferentiated cells at the apex of gill filament. The mitochondria-rich cells gave a positive reaction with PPAR $\gamma$ which indicated a role of PPAR $\gamma$ in osmoregulation process performed by MRCS. However, PPAR $\alpha$ was highly positive in red blood cells which suggested its role in respiration process. In all examined ages there was a high number of proliferative and apoptotic cells widely distributed all over the gills. An essential role of PPAR $\gamma$ in the process of osmoregulation was observed and an important role of PPAR $\alpha$ in the respiratory function of gills. As well as, we distinguished the ability of gills epithelial cells to proliferate under the control of PCNA and KI67 for the maintenance of normal gill structure in hazard conditions. Also damaged cells undergo apoptosis process under the control of BAX and the anti-apoptotic process performed in gills under the control of BCL2 gene.

Keywords: PPAR $\alpha$, PPAR $\gamma$, apoptosis, BCL2, MRCs, Gills, Mugil Cephalus

(http://www.bvmj.bu.edu.eg)

(BVMJ-35(2): 436-445, 2018)

\section{INTRODUCTION}

Mugil cephalus is a euryhaline fish species that can accommodate in both freshwater and saltwater and is a crucial economically fish (Li et al., 2017). The gills are composed of four holobranchs. Each holobranch contains several lamellae which 
act as gas exchange barrier as a highly vascularized layer of pillar cells surround them (Wilson and Laurent, 2002). The gills have many functions including; acid-base balance, gas exchange, excretion of nitrogenous waste products and osmoregulation (Evans et al., 2005). The mitochondria-rich cells (chloride cells) function as ionic regulators while pavement cells their function is a gas exchange (Evans et al., 2005; Hwang et al., 2011; Perry, 1998). On euryhaline fish, the mitochondria-rich cells (MRCs) have the property of change from freshwater kind to the saltwater kind and vice versa as a method for acclimation of gills to change of water kind (Ching et al., 2013). The gills from larval, juvenile and young Mugil cephalus fish observed by the aid of scanning electron microscopy which showed that the differentiation and development of gills were following growth and physiological function (Youjun et al., 2014).

Peroxisome proliferator activated receptors (PPARs) control lipids and carbohydrate metabolism, so they act as a source for energy production needed for cell proliferation and differentiation and for optimum immune function ((Desvergne and Wahli, 1999; Michalik and Wahli, 2006). Because mitochondria have an essential role in metabolism and oxidation of lipids, so there is a close relationship between PPARs and mitochondria (Darley-Usmar, 2004; Scatena et al., 2007). The role of BCL-2 family genes not studied well in teleosts and it was found that BCL-2 genes have an essential part in stress response in channel catfish by their potential role in controlling apoptosis process (Yuan et al., 2016). The close relationship between cell proliferation and $\mathrm{Ki}-67$ expression points to a position in cell growth or division (Schlüter et al., 1993). The PCNA protein is an indicator of cell proliferation (Horng et al., 2009; Sollid et al., 2003). In fish exposed to metal toxicity, the proliferation property of cells in their gills increased significantly with metals toxicity then followed by apoptosis after prolonged exposure to toxicity (Hermenean et al., 2017).

This study aimed to describe the histological observations of gills of Mugil cephalus fish at the age of three months, six months, eight months and one year. Also, evaluation of the role of PPAR $\alpha, \operatorname{PPAR} \gamma$, BCL-2, BAX, KI67, and PCNA in gill epithelium by using Immunofluorescence technique.

\section{MATERIALS AND METHODS}

\subsection{Fish sampling and histology}

This study carried on the twenty Mugil Cephalus fishes collected from mugil farm in Egypt at ages of three months, six months, eight months and one year. Five fishes used in each age group. After anesthesia of fishes, the gills were collected and preserved in $4 \%$ paraformaldehyde overnight, then dehydrated in upgrades of ethanol alcohol, cleared in xylene and embedded in paraffin wax. Serial sectioning obtained by microtome at $5 \mu \mathrm{m}$ and stained with hematoxylin and eosin stain for further histological observation, then examined by Zeiss light microscope for taking photos.

\subsection{Immunofluorescence}

The previously obtained sections were deparaffinized with xylene and dehydrated with upgrades of ethanol, then washed twice by phosphate-buffer saline (PBS) PH 7.4. The slides then we made antigen retrieval by sodium citrate buffer at $95^{\circ} \mathrm{C}$ for 20 minutes. Then the tissue sections were washed with PBS for three times. Then the sections were blocked with bovine serum at room temperature for one hour, and then were incubated with the appropriate primary antibodies at $4{ }^{\circ} \mathrm{C}$ overnight in a closed humid chamber. All the primary antibodies were diluted by $1 / 500$. Then sections were washed with PBS three times. Then the sections were 
incubated at room temperature for 1 hour with secondary antibodies labeled with appropriate secondary dye at a dilution1/400. It's necessary to carry out the incubation period in dark place to avoid bleaching of fluorochrome. The list of primary and secondary antibodies used in Immunofluorescence is showed in table (1). Then the slides were washed by PBS then coverslip mounted with an anti-fading medium, then observed with a confocal microscope for taking photos.

\section{RESULTS}

\subsection{Histology}

The gills of Mugil cephalus fish formed from gill arch which supports two rows of gill filaments (primary lamellae) and two rows of gill rakers. Many secondary lamellae projected from both sides of each gill filament. In this study, we focused on the histological observations of the gill filaments. At the age of three months, the gill filament supported by small part of hyaline cartilage located at the apex of each gill filament under a mass of undifferentiated cells, the gill filament was multilayered; from it the secondary lamellae projected (Fig. 1A). There were several types of cells forming the primary and secondary lamellae; pavement cell (spindle-shaped cell), mitochondria-rich cells (which have eosinophilic cytoplasm and eccentric nucleus), red blood cells and a small group of melanin-containing macrophages located at the apex of gill filament (Fig. 1B \& C). At the age of six months, several lacuna, mitochondria-rich cells, and mucous cells were noticed in secondary lamellae (Fig. 1D). At the age of eight months, there was a noticeable increase in the length of gill filament and increase in connective tissue fibers and hyaline cartilage which support it. Both primary and secondary lamellae resemble that at the age of six months except in slight increase in size (Fig. 1E). The gills reached complete development at the age of one year, some gills contain hyaline cartilage all over their length, and others have an empty central core with a noticeable lacunae pillar cells (Fig. 1F).

\subsection{PPAR $\alpha$ and PPAR immunofluorescence}

The peroxisome proliferator-activated receptors (PPARs) $\alpha$ and $\gamma$ expression was examined at different stages of gill development. It was found that at the age of three months, PPAR $\gamma$ was present in the mitochondria-rich cells which present in the primary lamellae and in the apex of each gill filament. The negative result was observed in the cells present in secondary lamellae due to the absence of mitochondria-rich cells in the secondary lamellae (Fig. 2A \& B). While PPAR $\alpha$, reacted positively with most kinds of cells present in both primary and secondary lamellae (data not shown). At age of eight months, PPAR $\alpha$ also was found in the same sites like that at the age of 3 months (Fig. 2C).

Also, PPAR $\gamma$ at the age of eight months showed the same results like that at the period of three months, except for very few cells in the secondary lamellae also showed positive results (Fig. 2D). At the age of one year, many cells in both primary and secondary lamellae showed positive result to both PPAR $\alpha$ and PPAR $\gamma$ (Fig. 2E \& F).

3.3 Detection of apoptotic and proliferator cells during gill development

For detection of apoptotic cells BAX was used, for detection of proliferator cells KI67 and PCNA were used, and the BCL2 was used to show cells with anti-apoptotic properties. The BCL2 showed in all examined ages high positive reaction with red blood cell. At the age of six months old BCL2 was found to be in some mitochondria-rich cells at the apex of the gill filament (Fig. 3A). While at the age of one year, the BCL2 positive reaction was mainly concentrated in the 
peripherally located red blood cells at the apex of gill filament and some few cells in the primary and secondary lamellae (Fig. 3B). Both BAX and KI67 showed a positive result in red blood cells and mitochondria-rich cells in the primary and secondary gill lamellae
(Fig. 3C \& D). PCNA showed positive results in mitochondria-rich cells and red blood cells which present in both primary and secondary gill lamellae, mitochondria-rich cells and also in the undifferentiated cells which found in the apex of gill filament (Fig. 3E \& F).

Table1:- The primary and secondary antibodies used in Immunofluorescence study

\begin{tabular}{lll}
\hline Primary antibody & secondary antibody labeling material
\end{tabular}

Rabbit polyclonal anti-PCNA antibody

Rabbit polyclonal anti-PPAR alpha antibody

Rabbit polyclonal anti-PPAR gamma antibody

Rabbit polyclonal anti-BAX antibodies

Rabbit polyclonal anti-Ki67 antibody

Rabbit polyclonal anti-BCL2 antibody goat anti-rabbit IgG

goat anti-rabbit $\operatorname{IgG}$

goat anti-rabbit $\operatorname{IgG}$

goat anti-rabbit IgG

goat anti-rabbit IgG

goat anti-rabbit $\mathrm{IgG}$

\section{CY3}

CY3

FITC

FITC

FITC

CY3 


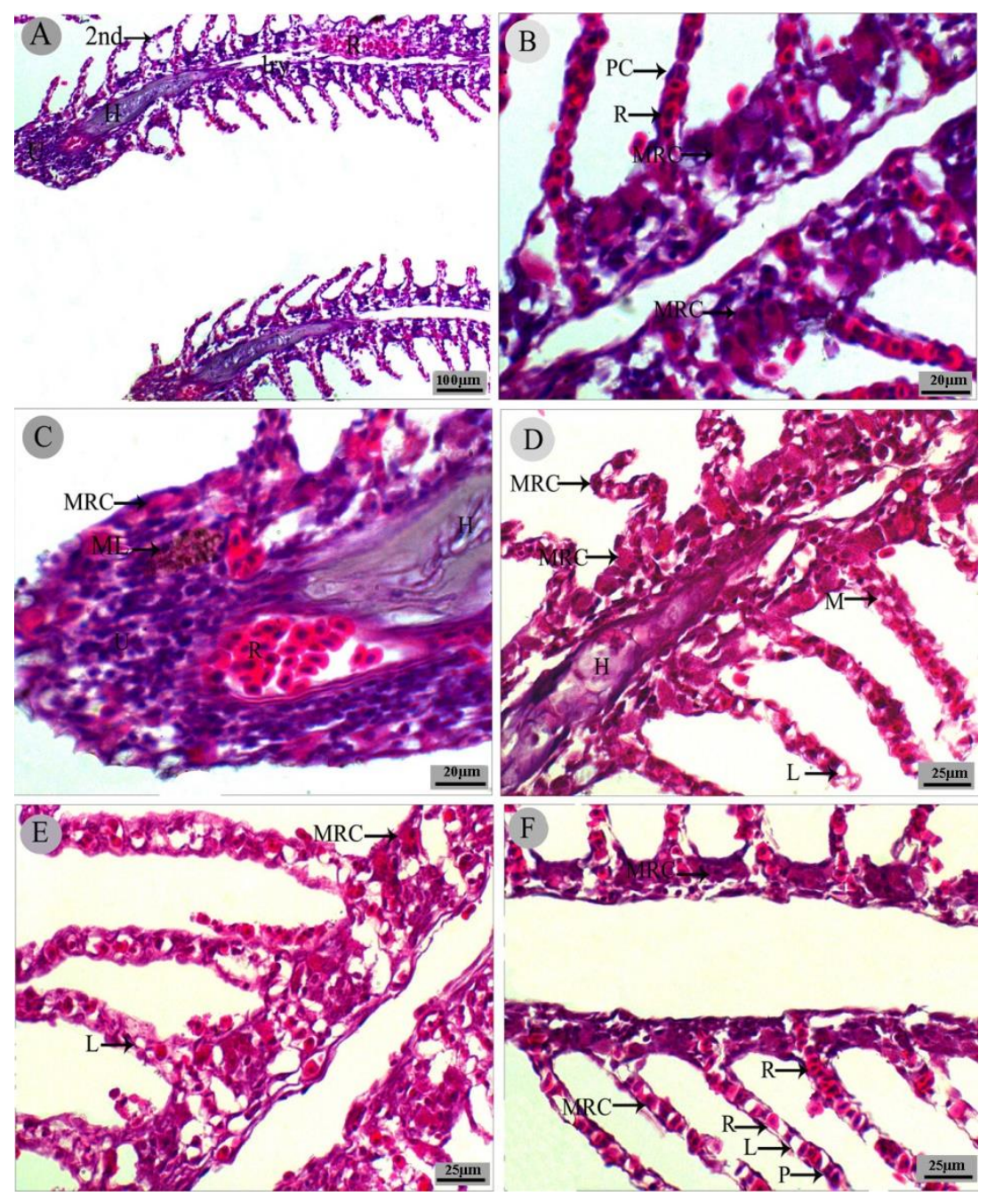

Figure 1. The gills of gray mullet fish at different ages, stained with hematoxylin and eosin stain. (A), (B) and (C) show gills at the age of three months. (D) At the age of six months. (E) At the age of eight months. (F) At the age of one year. Primary filament (1ry), secondary filament (2nd), hyaline cartilage $(\mathrm{H})$, red blood cells $(\mathrm{R})$, undifferentiated cells (U), pavement cells (PC), mitochondria-rich cells (MRC), hyaline cartilage $(\mathrm{H})$, macrophage containing melanin pigment (ML), lacuna (L), mucous cells (M) and pillar cells (P). 

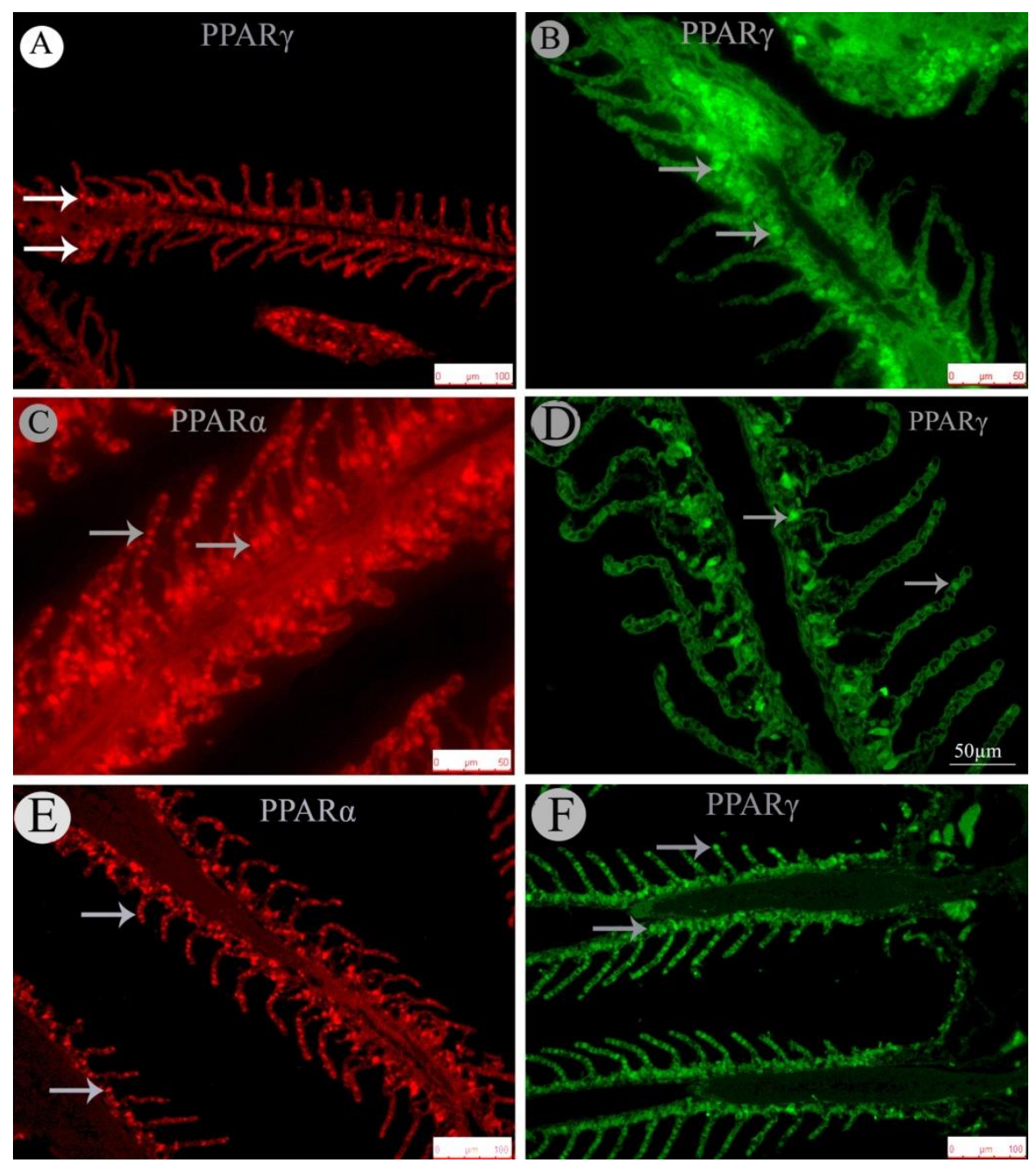

Figure 2. Immunofluorescence of peroxisome proliferator-activated receptors $\alpha$ and $\gamma$ in gills of gray mullet. (A) and (B) gills at the age of 3 months, show the positive reaction of MRCS in primary lamellae against PPAR $\gamma$ (arrows). (C) and (D) gills at the age of 8 months, (C) show the positive reaction of MRCS and red blood cells against PPAR $\alpha$ in primary and secondary lamellae and (D) show the positive reaction of MRCS against PPAR $\gamma$ in the primary lamellae and very rare in secondary lamellae (arrows). (E) And (F) gills at the age of one year, both PPAR $\alpha$ and PPAR $\gamma$ show a positive reaction in primary and secondary lamellae (arrows). 

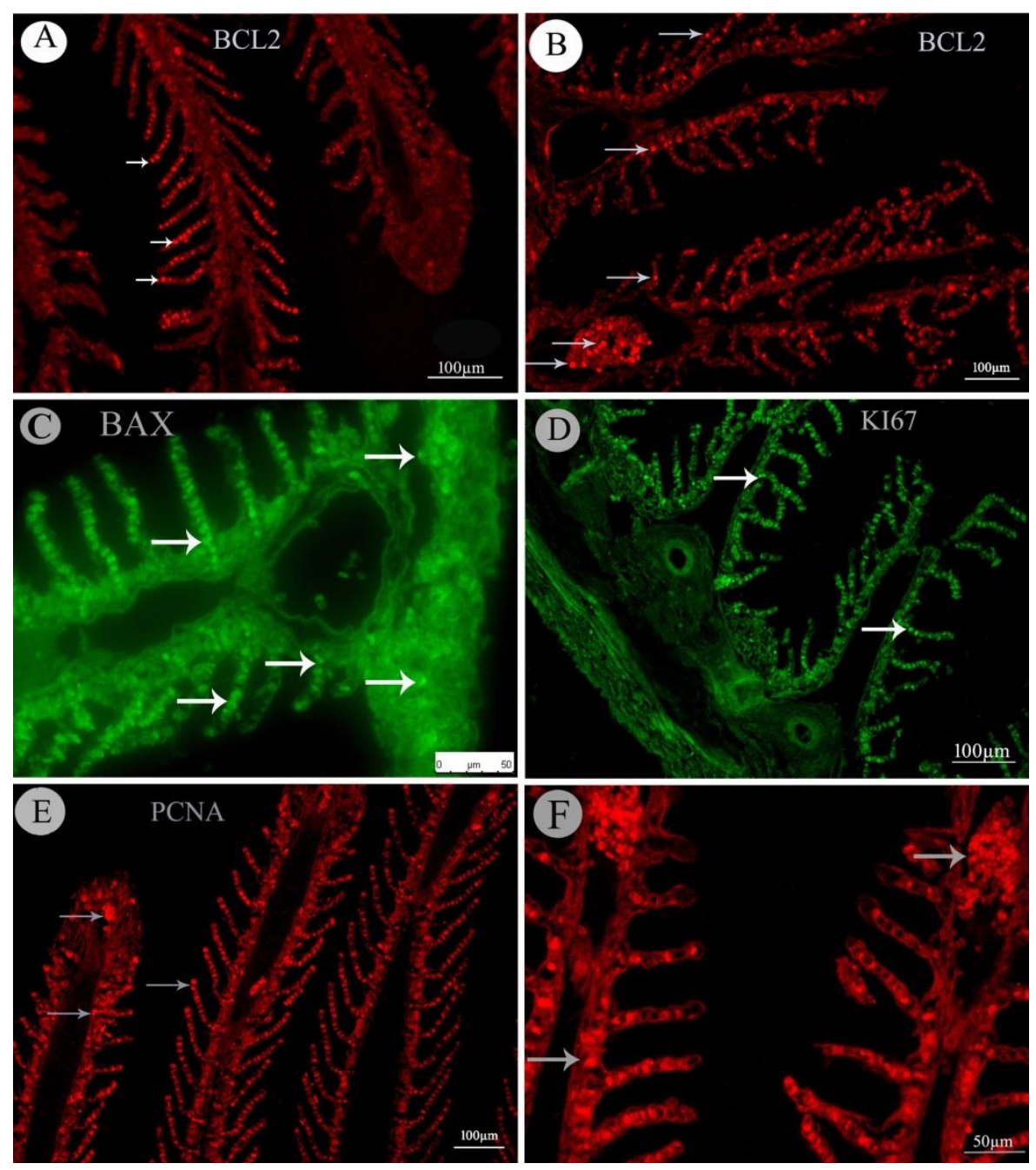

Figure 3. Immunofluorescence for BCL2, BAX, KI67, and PCNA in gills of gray mullet. (A) Gills at the age of 6 months show a positive reaction against BCL2 in secondary lamellae (arrows). (B) Gills at one year age show a positive reaction against BCL2 in primary, secondary lamellae and RBCs in the apex of gill filament (arrows). (C) And (D) Gills at the age of one year, show a positive reaction against BAX and KI67 respectively in both primary and secondary lamellae (arrows). (E) And $(\mathrm{F})$ gills at the age of one year, show a positive reaction against PCNA in the primary, secondary lamellae, and RBCs in the apex of gill filament (arrows).

\section{DISCUSSION}

The gill filament of Mugil cephalus contains several layers of cells and from which several secondary lamellae project. There were several types of cells forming primary and secondary lamellae were mitochondriarich cells (MR cells), pavement cell, red blood cells, pillar cells, mucous cells and melanomacrophage cells. While (Degnan et al., 1977; Wilson and Laurent, 2002) described the gill epithelium to be composed of four major cell types were mucous cells, pavement cells, non-differentiated cells and ionocytes (chloride cells). In teleosts, mitochondrion-rich (MR) cells, or chloride cells, are involved in acid-base regulation for freshwater and seawater adaptation. So an 
MR-cell function is very important for teleosts during migration to another kind of water (Kaneko et al., 2008; Kang et al., 2015; Marshall, 2010; Shieh et al., 2003; Uchida et al., 2000). As Mugil Cephalus fish is saltwater fish but migrate to freshwater fish (euryhaline fish) so its MR cells able to secrete and absorb ions in salt and fresh water respectively. The mitochondria-rich cells of Mugil cephalus fish were observed in the gill filament only and very rare in secondary lamellae; this result agrees with (Kaneko et al., 2008) who reported that MR cells moderately developed in both filaments and lamellae of freshwater fish. While in seawater-adapted fish, welldeveloped MR cells were detected only in the filament. While edema of epithelial cells, hypertrophy, congestion of blood in secondary lamellae and mucus deposition with lamellar fusion usually seen in metal toxicity as a compensatory mechanism of gills (Hermenean et al., 2017).

At all examined ages the MR cells which present in the gill filament epithelium reacted positively with PPAR $\gamma$ which indicates that mitochondria-rich cells obtain energy needed for the process of osmoregulation utilizing lipid oxidation under control of PPAR $\gamma$. However, only some mitochondriarich cells which present peripherally at the apex of gill filament reacted positively with PPAR $\alpha$ which indicate the little role of PPAR $\alpha$ in the process of osmoregulation in gray mullet fish. While PPAR $\alpha$ showed a noticeable positive reaction with red blood cells of gill filament and secondary lamellae. The red blood cell can carry oxygen during the process of respiration and obtain their energy need by the aid of PPAR $\alpha$. The PPARs expression is detected in tissues with high mitochondrial and peroxisomal $\beta$-oxidation capacity (Darley-Usmar, 2004; Desvergne and Wahli, 1999; Ibabe et al., 2005; Ibabe et al., 2004; Scatena et al., 2007).
Both BAX and BCL2 gave a positive reaction in red blood cells and mitochondriarich cells in all examined ages especially at the age of one year. Apoptosis process by BAX was previously found in mitochondria-rich cells (MRCs) in the climbing perch, Anabastestudineus (Ching et al., 2013). However, the BCL2 gene function is keeping cell live by its anti-apoptotic property (Yin et al., 1994).

The proliferator cells which were KI67 and PCNA positive were mitochondria-rich cells, the undifferentiated cells which found in the apex of gill filament and red blood cells. (Alison, 1995) Mentioned that the Ki-67 protein expression is thought to be an indicator for cells within the growth fraction of a given population. This high proliferation activity of these cells may increase as a compensatory mechanism during hypoxia to improve the respiratory process. Also (Saroglia et al., 2002) reported that the fish increased their gill respiratory surface area to uptake more ambient oxygen in a hypoxic environment. While (Mauceri et al., 2005) mentioned that only very few PCNA immune-reactive nuclei seen in the epithelial filaments.

\section{Acknowledgments}

This study was financially supported by the Fundamental Research Funds for the Central Universities of China (Project Number: 2662015PY033).

\section{REFERENCES}

Alison, M.R., 1995. Assessing cellular proliferation: what's worth measuring? Human \& Experimental Toxicology 14(12), 935-944.

Ching, B., Chen, X.L., Yong, J.H.A., Wilson, J.M., Hiong, K.C., Sim, E.W.L., Wong, W.P., Lam, S.H., Chew, S.F., Ip, Y.K., 2013. Increases in apoptosis, caspase activity and expression of p53 
and bax, and the transition between two types of mitochondrion-rich cells, in the gills of the climbing perch, Anabas testudineus, during a progressive acclimation from freshwater to seawater. Frontiers in Physiology 4, 135.

Darley-Usmar, V., 2004. The powerhouse takes control of the cell; the role of mitochondria in signal transduction. Free Radical Biology \& Medicine 37(6), 753-754.

Degnan, K.J., Jr, K.K.J., Zadunaisky, J.A., 1977. Active chloride transport in the in vitro opercular skin of a teleost ( Fundulus heteroclitus ), a gill-like epithelium rich in chloride cells. J Physiol 271(1), 155-191.

Desvergne, B., Wahli, W., 1999. Peroxisome proliferator-activated receptors: nuclear control of metabolism. Endocrine Reviews 20(5), 649-688.

Evans, D.H., Piermarini, P.M., Choe, K.P., 2005. The multifunctional fish gill: Dominant site of gas exchange, osmoregulation, acid-base regulation, and excretion of nitrogen waste. Physiological Reviews 85(1), 97-177.

Hermenean, A., Gheorghiu, G., Stan, M.S., Herman, H., Onita, B., Ardelean, D.P., Ardelean, A., Braun, M., Zsuga, M., Kéki, S., 2017. Biochemical, Histopathological and Molecular Responses in Gills of Leuciscus cephalus Exposed to Metals. Archives of Environmental Contamination \& Toxicology 73(4), 607-618.

Horng, J.L., Lin, L.Y., Hwang, P.P., 2009. Functional regulation of H+-ATPaserich cells in zebrafish embryos acclimated to an acidic environment. American Journal of Physiology Cell Physiology 296(4), C682.
Hwang, P.P., Lee, T.H., Lin, L.Y., 2011. Ion regulation in fish gills: recent progress in the cellular and molecular mechanisms. American Journal of Physiology Regulatory Integrative \& Comparative Physiology 301(1), R28.

Ibabe, A., Bilbao, E., Cajaraville, M.P., 2005. Expression of peroxisome proliferatoractivated receptors in zebrafish (Danio rerio) depending on gender and developmental stage. Histochemistry \& Cell Biology 123(1), 75-87.

Ibabe, A., Grabenbauer, M., Baumgart, E., Völkl, A., Fahimi, H.D., Cajaraville, M.P., 2004. Expression of peroxisome proliferator-activated receptors in the liver of gray mullet (Mugil cephalus). Acta Histochemica 106(1), 11-19.

Kaneko, T., Watanabe, S., Lee, K.M., 2008. Functional Morphology of Mitochondrion-Rich Cells in Euryhaline and Stenohaline Teleosts. Aqua-BioScience Monographs 1(1), 162.

Kang, C.K., Yang, S.Y., Lin, S.T., Lee, T.H., 2015. The inner opercular membrane of the euryhaline teleost: a useful surrogate model for comparisons of different characteristics of ionocytes between seawater- and freshwateracclimated medaka. Histochemistry \& Cell Biology 143(1), 69-81.

Li, L., Jiang, M., Shen, X.Q., 2017. Gene expressions levels of 14-3-3a, NKCCla, APO-14, and $\mathrm{Na}(+)-\mathrm{K}(+)-$ ATPase $\beta$ in gill tissue of Mugil cephalus acclimated to low salinity. Genetics \& Molecular Research Gmr $16(1)$.

Marshall, W.S., 2010. Na+, Cl-, Ca2+ and Zn2+ transport by fish gills: retrospective review and prospective synthesis (p\&nbsp;264-283). Journal of 
Experimental Zoology Part A Ecological Genetics \& Physiology 293(3), -.

Mauceri, A., Fossi, M.C., Leonzio, C., Ancora, S., Minniti, F., Maisano, M., Cascio, P.L., Ferrando, S., Fasulo, S., 2005. Stress factors in the gills of Liza aurata (Perciformes, Mugilidae) living in polluted environments. Italian Journal of Zoology 72(4), 285-292.

Michalik, L., Wahli, W., 2006. Involvement of PPAR nuclear receptors in tissue injury and wound repair. Journal of Clinical Investigation 116(3), 598-606.

Perry, S.F., 1998. Relationships Between Branchial Chloride Cells and Gas Transfer in Freshwater Fish. Comp Biochem Physiol A Mol Integr Physiol 119(1), 9-16.

Saroglia, M., Terova, G., Stradis, A.D., Caputo, A., 2002. Morphometric adaptations of sea bass gills to different dissolved oxygen partial pressures. Journal of Fish Biology 60(6), 1423-1430.

Scatena, R., Bottoni, P., Botta, G., Martorana, G.E., Giardina, B., 2007. The role of mitochondria in pharmacotoxicology: a reevaluation of an old, newly emerging topic. American Journal of Physiology Cell Physiology 293(1), C12.

Schlüter, C., Duchrow, M., Wohlenberg, C., Becker, M.H., Key, G., Flad, H.D., Gerdes, J., 1993. The cell proliferationassociated antigen of antibody $\mathrm{Ki}-67$ : a very large, ubiquitous nuclear protein with numerous repeated elements, representing a new kind of cell cyclemaintaining proteins. Journal of Cell Biology 123(3), 513.

Shieh, Y.E., Tsai, R.S., Hwang, P.P., 2003. Morphological Modification of
Mitochondria-Rich Cells of the Opercular Epithelium of Freshwater Tilapia, Oreochromis mossambicus, Acclimated to Low Chloride Levels. Zoological Studies 42(4), 522-528.

Sollid, J., De, A.P.K., Nilsson, G.E., 2003. Hypoxia induces adaptive and reversible gross morphological changes in crucian carp gills. Journal of Experimental Biology 206(20), 3667-3673.

Uchida, K., Kaneko, T., Miyazaki, H., Hasegawa, S., Hirano, T., 2000. Excellent Salinity Tolerance of Mozambique Tilapia (Oreochromis mossambicus): Elevated Chloride Cell Activity in the Branchial and Opercular Epithelia of the Fish Adapted to Concentrated Seawater. Zoological Science 17(2), 149-160.

Wilson, J.M., Laurent, P., 2002. Fish gill morphology: inside out. Journal of Experimental Zoology 293(3), 192.

Yin, X.M., Oltvai, Z.N., Korsmeyer, S.J., 1994. $\mathrm{BH} 1$ and $\mathrm{BH} 2$ domains of $\mathrm{Bcl}-2$ are required for inhibition of apoptosis and heterodimerization with Bax. Nature 369(6478), 321-323.

Youjun, O.U., Jiaer, L.I., Xie, J., Zhiming, M.A., Chen, Y., 2014. Study on gill ultrastructure and respiratory area in early developmetal stages of grey mullet( Mugil cephalus). South China Fisheries Science 10(4), 52-57.

Yuan, Z., Liu, S., Yao, J., Zeng, Q., Tan, S., Liu, Z., 2016. Expression of Bcl-2 genes in channel catfish after bacterial infection and hypoxia stress. Developmental \& Comparative Immunology 65, 79 . 